\title{
Arvo Ikonen
}

\section{Autonomia vaarassa}

\begin{abstract}
Ikonen, Arvo. 1984. Autonomia vaarassa. Aikuiskasvatus 4, 2, 82-89. - Artikkeli perustuu ihmisten heteronomisen ja autonomisen toiminnan tarkastelulle. Vapaan sivistystyön aatteen nähdään rakentuvan ihmisten autonomisen toiminnan pohjalle. Artikkelissa kritisoidaan sitä maassamme harjoitettua vapaan sivistystyön kehittämistoimintaa, joka tapahtuu aikuiskoulutuksen kehittämisen puitteissa. Kansalaisopistojen kehittämistä päädytään esittämään sellaisiksi paikallisiksi sivistystyön keskuksiksi, joiden vastuulla olisi koko paikallinen sivistystyö. Samalla muutettaisiin nykyisten sivistysjärjestöjen toiminta lähes täydellisesti.
\end{abstract}

Vapaata sivistystyötä voidaan tarkastella joko valtionhallinnon ja valtiollisen suunnittelun tai kansalaisten ja heidän toimintansa näkökulmasta.

Seuraavassa tarkastelen vapaata sivistystyötä ja sen kehittämistä kansalaisen ja hänen toi- mintansa näkökulmasta. Mielestäni tämä näkökulma on jäänyt taka-alalle erityisesti 1970luvulla. Tällöin valtiovalta lisäsi vapaan sivistystyön hallinnointia eli rajoitti sen mahdollisuuksia yhdistämällä vapaan sivistystyön kehittämisen ja aikuiskoulutuksen valtiollisbyrokraattisen suunnittelun. 


\section{Kansalaisten autonomia ja vapaa sivistystyö}

Yhteiskunnan jäsenenä ja kansalaisena ihminen on pakotettu osallistumaan heteronomisiin toimintoihin. Niihin kuuluvat ennen kaikkea työtoiminta ja valtiokoneiston toiminta. Heteronominen toiminta on ulkoapäin määräytyvää ja ohjautuvaa. Mutta voidakseen olla yhteiskunnan jäsen ja kansalainen ihmisen on voitava toimia myös autonomisesti. Autonominen toiminta on yksilöstä itsestään lähtevää, hänen itsensä määräämää, omaehtoista ja itseohjautuvaa.

Heteronominen toiminta vieraannuttaa ihmistä itse toiminnasta, sen tuloksista ja muista siihen osallistuvista ihmisistä. Heteronomiseen toimintaan osallistuville ihmisille yhteiskunta on kuin jättiläismäinen kone, jonka yhtenä osana hän joutuu toimimaan. Tämä "kone" ja sen toiminta on hänelle vieras ja ulkopuolinen mahti. Yhteiskunta ja sen rakenteet eivät ole ihmisen omaa aikaansaannosta, vaan hän joutuu toimimaan yhteiskunnallisissa rakenteissa, jotka ovat jo olemassa ennen häntä. Siksi on luonnollista ja hyvin inhimillistä, että yhteiskuntarakenteiden mukaisessa toiminnassa ihminen vieraantuu. Jos ihminen ei vieraantuisi heteronomisessa toiminnassa, hän täydellisesti sosiaalistuisi eli sopeutuisi ja integroituisi yhteiskuntaan ja sen vallitseviin rakenteisiin. Yhteiskunta ja sen erilaiset instituutiot pyrkivät sosiaalistamisprosessin avulla siirtämään vallitsevat arvot, normit, tiedot, uskomukset ja taidot sukupolvelta toiselle. Jos sosiaalistamisprosessi onnistuisi täysin ja kaikkien ihmisten osalta, päätyisimme täydelliseen totalitaariseen yhteiskuntaan.

Ihmisten vieraantuminen heteronomisessa toiminnassa toimii sosiaalistamisprosessia vastaan. Vaikka ihminen joutuu toimimaan heteronomisesti, hän toimii aina samalla myös jossain määrin autonomisesti eli vieraantuu. Heteronominen toiminta, kuten esim. työtoiminta, ei tyydytä ensisijaisesti ihmisten omia tarpeita ja pyrkimyksiä. Niitä voi tyydyttää vain autonominen toiminta.

Autonominen toiminta on luonteeltaan luovaa. Siinä ihminen luo omia arvoja, normeja, uskomuksia, tietoja ja taitøja. Siksi ei ole mikään ihme, että kaikissa yhteiskunnissa valtakoneistot näkevät autonomisen ja luovan toiminnan uhkaavan kuria ja järjestystä.
Vapaan sivistystyön aate perustuu ajatukselle autonomisesta toiminnasta, sen tukemisesta ja lisäämisestä. Ilman ihmisten autonomian ja autonomisen toiminnan avointa tunnustamista ei voi olla myöskään vapaata sivistystyötä. Vain valtiota, joka hyväksyy vapaan sivistystyön ja tukee sitä eri tavoin, voi nimittää sivistysvaltioksi.

Mutta myös sivistysvaltioissa, joihin $\mathrm{mm}$. Suomi kuuluu, täytyy jatkuvasti taistella vapaan sivistystyön tunnustamisen ja tukemisen puolesta. Viime vuosikymmeninä ovat ns. länsimaiset yhteiskunnai sekä tavaramuotoistuneet että valtiollistuneet. Ts. yhä useammat yhteiskunnan toiminnot ovat tulleet sekä tavaratuotannon että valtion toiminnan piiriin. Tämä on merkinnyt heteronomisten toimintojen lisääntymistä.

Seuraavassa tarkastelen autonomiaa Suomen vapaassa sivistystyössä. Erityisesti keskityn tarkastelemaan sitä, lisäävätkö vai vähentävätkö nykyiset valtionapujärjestelmät vapaan sivistystyön piirissä toimivien opiskeluryhmien autonomiaa.

Vapaalla sivistystyöllä ymmärrän kansalaisja työväenopistojen, kansanopistojen, sivistysjärjestöjen ja niiden ylläpitämien opintokeskusten piirissä tapahtuvaa autonomista eli vapaaehtoista ja omaehtoista opiskelua. Tämän opiskelun avulla ei tähdätä tutkintoihin tai muodollisen pätevyyden hankkimiseen. Opiskelu ei palvele ulkopuolisten asettamia vaatimuksia, vaan se palvelee kansalaisten omia itsekasvatuspyrkimyksiä. Opiskelu ei ole luonteeltaan välineellistä, vaan se on sinänsä itsearvoista toimintaa.

Edellä esittämäni ajatus kansalaisten opiskelun autonomisuudesta vapaan sivistystyön lähtökohtana edellyttää

1) koko vapaan sivistystyön järjestelmän autonomiaa suhteessa julkiseen valtaan,

2) vapaan sivistystyön järjestelmän muodostavien organisaatioiden ja laitosten autonomiaa suhteessa sekä julkiseen valtaan että muihin organisaatioihin

3) vapaan sivistystyön organisaatioiden ja laitosten piirissä toimivien opiskeluryhmien autonomiaa suhteessa sekä julkiseen valtaan että muihin organisaatioihin.

Seuraavassa käsittelen lähemmin autonomian toteutumista kullakin em. tasolla. Samalla esitän eräitä ajatuksia siitä, miten vapaa sivistystyö olisi organisoitava ja valtionapujärjestelmiä uusittava, jotta autonomiaa voitaisiin lisätä em. tasoilla. 


\section{Vapaan sivistystyön järjestelmän autonomia}

Koko vapaan sivistystyön järjestelmän autonomiaa suhteessa valtiovaltaan on pyritty vähentämään kuluneen vuosikymmenen aikana. Selvimmin tämä pyrkimys on toteutunut ns. aikuiskoulutuksen kehittämisessä ja sen organisoimisessa. Vuoden 1971 aikuiskoulutuskomitea pyrki integroimaan vapaan sivistystyön osaksi aikuiskoulutusjärjestelmää. Valtioneuvoston vuonna 1979 asettama aikuiskoulutuksen väliaikainen kehittämisorganisaatio on jatkanut aikuiskoulutuskomitean työtä ja vapaan sivistystyön kehittäminen integroitiin ja alistettiin aikuiskoulutuksen kehittämisen osaksi. Ajatus erillisestä vapaan sivistystyön kehittämisorganisaatiosta torjuttiin. Aikuiskoulutuksen kehittämisorganisaatioon otettiin vapaan sivistystyön edustajia vain "ottopojiksi".

Opetusministeriön asettaessa erillisiä aikuiskoulutuksen kehittämistoimikuntia pirstottiin vapaan sivistystyön organisaatioiden ja laitosten toiminnan kehittäminen usean toimikunnan kesken. Erikseen asetettiin kansanopistotoimikunta, järjestöllisen sivistystyön toimikunta ja kunnallisen aikuiskoulutuksen toimikunta.

Vapaan sivistystyön toiminnan kehittämisessä valtiovalta lähti liikkeelle 'hajoita ja hallitse" -menetelmästä. Ensiksi valtiovalta alisti vapaan sivistystyön kehittämisen aikuiskoulutuksen osaksi. Toiseksi valtiovalta pirstoi vapaan sivistystyön kehittämisen erillisille toimikunnille. Siksi on täysin ymmärrettävää, että valtiovalta ja ennen kaikkea valtiovarainministeriö saattoivat suorittaa hyökkäyksen koko rintamalla vapaata sivistystyötä ja sen valtionapujärjestelmiä vastaan niiden kehittämisen, yksinkertaistamisen ja yhdenmukaistamisen varjolla. Kaikki toimikunnat nielivät valtiovarainministeriön "täyn" eli suoriteperusteisen valtionapujärjestelmän.

Toimikuntien esittämät, hyvin kirjavat ja keskenään ristiriitaiset suoriteperusteiset valtionapujärjestelmät merkitsevät koko sivistystyön järjestelmän autonomian vähentymistä suhteessa valtiovaltaan. Tämä asia onkin nähty vapaan sivistystyön piirissä. Siksi sivistysjärjestöt ovat toimikuntien mietinnöistä antamissaan lausunnoissa suuntautuneet kielteisesti suoriteperusteisiin valtionapujärjestelmiin. Tämä onkin luonnollista, mikäli vapaata sivistystyötä tekevät organisaatiot ja laitokset haluavat säilyttää nykyisen autonomiansa ja jopa sitä lisätä.

\section{Vapaan sivistystyön laitosten ja oganisaatioiden autonomia}

Sivistysjärjestöillä tarkoitan niitä opintokeskusta ylläpitäviä järjestöjä, joita on tällä hetkellä 10 . Sivistysjärjestöthän ovat valtakunnallisia järjestöjä, joiden jäseninä on erilaisia useimmiten valtakunnallisia keskusjärjestöjä. Sivistysjärjestöjen jäseninä on puolueita, ammattiliittoja ja muita etujärjestöjä, kulttuurijärjestöjä ja aatteellisia järjestöjä. Sivistysjärjestöjen johtoelimiin kuuluu etupäässä jäsenjärjestöjen johtohenkilöitä. Sivistysjärjestöt ovat lisäksi rakenteeltaan hyvin hierarkkisia ja toiminnassaan hyvin byrokraattisia. Edelleen sivistysjärjestöjen toiminta on hyvin keskitettyä eli keskustoimistokeskeistä. Voi sanoa, että sivistysjärjestöt ovat samanaikaisesti sekä järjestöbyrokratian että valtiobyrokratian jatkeita. Sivistysjärjestöjen johtamisessa tämä näkyy korporatiivisena hallintokäytäntönä.

Sivistysjärjestöjen autonomia suhteessa valtiovaltaan on vähentynyt kuluneen vuosikymmenen aikana. Vuoden 1975 opintokeskuslain myötä sivistysjärjestötoiminnan valtaosa tuli lain alaiseksi opintokeskustoiminnaksi ja sivistysjärjestöt saivat ratkaisevasti lisää valtionapua toimintansa rahoittamiseen. Mutta vastaavasti opintokeskuslain alainen toiminta tuli kouluhallituksen pikkumaisen valvonnan piiriin. Parhaana esimerkkinä tästä on lyhytkurssien valtionapumenettely. Näin opintokeskuslaki merkitsi kokonaisuudessaan sivistysjärjestöjen autonomian ratkaisevaa vähentymistä.

Järjestöllisen sivistystyön toimikunta ehdottaa mietinnössään lakia sivistysjärjestöjen valtionavusta. Lakiesityksen mukaan koko sivistysjärjestötoiminta tulisi vältionhallinnon eli lain, asetuksen ja kouluhallituksen antamien määräysten ja ohjeiden säätelemäksi toiminnaksi. Toimikunta ehdottaa, että lakisääteisen valtionavun piiriin tulisivat kaikki ne sivistysjärjestöjen perustoiminnot, jotka vielä nyt ovat opintokeskuslain ulkopuolella, kuten esim. kulttuuriharrastustoiminta ja opintoaineistojen tuottaminen. Toisin sanoen toimikunta ehdottaa sivistysjärjestöjen ja opintokeskusten välisen eron hävittämistä eli koko sivistysjärjestön muuttamista luonteeltaan laajennetuksi opintokeskukseksi. Ehdotettu lakiuudistus merkitsisi sivistysjärjestöjen muuttumista kokonaisuudessaan vain valtionavun välitysyksiköiksi ja valtiobyrokratian suoranaisiksi jatkeiksi. Järjestöllisen sivistystyön toimikunnan ehdotukset sivistysjärjestölaiksi mer- 
kitsevät nykyiseen tilanteeseen verrattuna sivistysjärjestöjen autonomian jyrkkää vähenemistä valtiovallan suhteen.

Järjestöllisen sivistystyön toimikunnalta puuttui itseymmärrystä sekä oman että koko vapaan sivistystyön suhteen. Muuten ei voinut ollakaan. Olihan toimikunta muodostettu henkilöistä, jotka eivät toimi vapaan sivistystyön ' 'kentällä', vaan jotka toimivat järjestöllisen sivistystyön . ja valtionhallinnon hierarkian "'huipulla". Näin ollen oli luonnollista, että toimikunta ei osannut erottaa toisistaan vapaata sivistystyötä ja sitä tukevia valtionapujärjestelmiä, vaan se päinvastoin ehdotuksissaan samaisti nämä kaksi luonteeltaan vastakkaista asiaa toisiinsa. Eihän tarvitse ollenkaan lähteä siitä, että sivistysjärjestöjen pitäisi toimia valtionavun välittäjinä. Tämän tehtävänhän voisi itse asiassa kaikista keskitetyimmin hoitaa ilman välikäsiä kouluhallituksen kurssi-, luento- ja opintokerhotoimisto!

Sivistysjärjestöt ovat alkuaan syntyneet edistämään kansalaisten vapaita sivistyspyrkimyksiä. Mutta opintokeskuslain myötä ne muuttuivatkin pääasiassa valtionaputoimistoiksi. Kuitenkaan tämä tilanne ei saa merkitä sitä, etteik.̈ voisi vaàtia, että sivistysjärjestöt saisivat takaisin alkuperäisen roolinsa aatteellisina yhteenliittyminä ja että sivistysjärjestöiltä jäisi pois sellaisia tehtäviä, jotka eivät niille kuulu.

Kansalaisopistoilla tarkoitan työväen-, kansalais- ja vapaáopistoja. Niitä on lähes 280 eri puolilla Suomea. Kunkin opiston toimintaalueena on yksi tai useampi kunta. Lähes kaikki Suomen kunnat ovat tällä hetkellä jo jonkin opiston toiminnan piirissä. Voi sanoa, että kansalaisopistojärjestelmä on hyvin hajautettu ja huomattavasti vähemmän hierakkinen kuin sivistysjärjestöjärjestelmä.

Kansalaisopistojen autonomia suhteessa valtioon on viime vuosina vähentynyt sitä mukaa kuin valtiovallan harjoittama säätely ja valvonta ovat lisääntyneet. Opistojen valtionosuusjärjestelmä on melko byrokraattinen ja holhoava. Kouluhallituksen määräykset eivät kohdistu vain opistojen hallintoon ja talouteen, vaan myös opetukseen.

Kuitenkin kansalaisopistojen asema on alusta alkaen ollut huomattavasti autonomisempi kuin opintokeskusten asema. Onhan kansalaisopistojen toiminnan sisältönä opetuksen järjestäminen ja antaminen eikä valtionavun välittäminen. Kansalaisopistot eivät ole valtionhallinnon jatkeita ja valtionavun välittäjiä kuten opintokeskukset. Lisäksi valtaosa kansalaisopistoista on kunnallisia opistoja, joita johtavat kunnanvaltuuston valitsemat johto- kunnat. Yksityisten opistojen taustalla on kannatusyhdistys. Näin ollen kansalaisopistot eivät ole eivätkä voi olla riippuvaisia valtakunnallisista keskusjärjestöistä. Kansalaisopistot eivät näin ollen ole myöskään järjestöbyrokratian jatkeita kuten opintokeskukset.

Kunnallisen aikuiskoulutustoimikunnan kansalaisopistojen toimintaa koskevat lakiesitykset merkitsevät toteutuessaan kansalaisopistojen autonomian vähentymistä suhteessa valtiovaltaan. Erityisesti suoriteperusteinen valtionapujärjestelmä ja opetustuntien kiintiöinti lisäisivät kouluhallituksen ja erityisesti valtiovarainministerion valtaa määrätä opistojen toiminnasta.

Kansanopistoilla tarkoitan kansanopistoja ja kansankorkeakouluja. Yksityisiä kansanopistoja on Suomessa 89 eri puolilla maata. Kunkin opiston toiminta-alueena on koko maa tai tietty maakunta. Voi sanoa, että kansanopistojärjestelmä on melko hajautettu ja vähemmän hierarkkinen kuin opintokeskusjärjestelmä.

Kansanopistojen autonomia suhteessa valtioon on pysynyt viime aikoina ennallaan. Lisäksi kansanopistojen asema valtion suhteen on opintokeskuksiin verrattuna autonomisempi. Onhan kansanopistojen toiminnan sisältönä opetuksen järjestäminen ja antaminen eikä valtionavun välittäminen. Näin ollen kansanopistot eivät ole mitään valtionaputoimistoja. Kuitenkin kansanopistojen toimintaa säätelee taustayhteisöjen byrokratia samaan tapaan kuin opintokeskuksiakin. Erityisesti ns. järjestöopistoja säätelee niitä ylläpitävien yhteisöjen byrokratia, kun taas ns. maakuntaopistoja järjestöbyrokratia säätelee erittäin vähän.

Tällä hetkellä sekä kansanopistojen että opintokeskusten lyhytkurssitoiminta on päällekkäistä. Ja tämä päällekkäisyys lisääntyy sitä mukaa kuin kansanopistojen toiminnan painopiste siirtyy vuosikursseista lyhytkurssien järjestämiseen. Jos kansanopistotoimikunnan esitys lyhytkurssien vähimmäispituuden alentamisesta kolmeen päivään toteutetaan, lisääntyy opintokeskusten ja kansanopistojen päällekkäistoiminta huomattavasti.

Toteutuessaan kansanopistotoimikunnan lakiesitykset merkitsevät kansanopistojen autonomian lisääntymistä. Kansanopistotoimikunnassa mukana olleet kansanopistojen rehtorit ovat valveutuneina "'kentän" edustajina kyenneet tästä huolehtimaan. Toteutuessaan kansanopistojen uusi valtionapujärjestelmä antaisi nykyistä väljemmät mahdollisuudet suunnitella ja organisoida opiston toimintaa ja opetusta. 


\section{Vapaan sivistystyön opiskeluryhmien autonomia}

Vapaan sivistystyön piirissä toimivien opiskeluryhmien, opintokerhojen, opintopiirien ja erilaisten lyhytkurssiryhmien autonomian aste suhteessa julkiseen valtaan ja muihin organjsaatioihin ja laitoksiin vaihtelee hyvin paljon.

Vähiten autonomiaa on kansanopistojen ja opintokeskusten erilaisilla lyhytkurssiryhmillä. Tavallisestihan kurssille osallistuvan osanottajaryhmän opiskeluprosessia ohjataan ulkoapäin. Ryhmän itseohjautuvuus on siis hyvin pieni ja ulkoa tapahtuva ohjaus on hyvin laajaa. Ulkoa tapahtuvaa ohjausta suorittavat valtiovalta valtionapusäädöksillä, lyhytkurssin järjestäjä opetussuunnitelmaratkaisuilla ja opettajavalinnoilla sekä opettaja omilla menettelyillään kurssin opiskelutilanteessa.

Lyhytkurssitoiminnassa kurssiryhmän työskentelyä säätelevät ja kontrolloivat hyvin tiukasti sekä valtiobyrokratia että järjestöbyrokratia. Erityisessä valtion holhouksessa ovat opintokeskusten lyhytkurssit. Kouluhallitushan hyväksyy ja käsittelee ne kurssikohtaisesti. Kansanopistojen kurssien käsittely on väljempää. Valtion lisäksi lyhytkurssitoimintaa säätelee hyvin tiukasti myös järjestöbyrokratia. Lyhytkurssithan ovat pääasiassa valtakunnallisten keskusjärjestöjen järjestämiä. Käytännössä lyhytkursseja panevat toimeen järjestöjen toimitsijat, jotka useimmiten toimivat kursseilla myös opettajina. Lähes poikkeuksetta lyhytkurssitoiminta palvelee keskusjärjestöjen byrokraattis-teknisiä tarpeita ja niiden johdon vallankäyttöä.

Eniten autonomiaa on opintokerhoryhmillä opintokeskusten toiminnassa. Tavallisestihan opintokerhoryhmän opiskeluprosessi ohjautuu sen sisältä käsinn, ts. opintokerhoryhmän itseohjautuvuus on hyvin suuri. Ulkoa tapahtuvaa ohjausta kyllä' on, mutta se on hyvin vähäistä. Valtiovalta ohjaa valtionapusäädöksillä ja opintokerhon taustayhdistys omilla päätöksillään. Opintokerhon valtionapusäädökset ohjaavat opintokerhon opiskeluprosessia melko vähän. Opintokerhon muodostanut ryhmä voi melko vapaasti suunnitella ja järjestää opiskelunsa eli päättää opiskelutavoitteistaan, valita opiskeltavat aiheet ja asiat, työskentelytavat, tietolähteet, opiskeluajat ja -paikat, ohjaajat ja asiantuntijat.

Opintokerhoryhmiä säätelee järjestöbyrokratia huomattavasti vähemmän kuin lyhytkurssiryhmiä. Tämä johtuu siitä, että opintokerho-opiskelu tapahtuu järjestöjen perusyhdistyksissä, joiden toiminta tapahtuu talkootyönä. Ts. opintokerhotoimintaa eivät toteuta päätoimiset järjestötoimitsijat vaan yhdistysten jäsenet. Tietysti järjestöt pyrkivät alistamaan myös opintokerho-opiskelun byrokraattis-teknisille tarpeilleen ja valtansa käytölle. Keinoina ovat vaikuttaminen opintokerhojen aiheiden ja oppimateriaalien valintaan. Hyvänä esimerkkinä tästä ovat ay-liikkeen opintokerhot.

Kansalaisopistojen opintopiiriryhmien autonomia on hieman suurempi kuin lyhytkurssiryhmien, mutta paljon pienempi kuin opintokerhojen. Tässä suhteessa opintopiiriryhmät muistuttavat enemmän lyhytkurssiryhmiä kuin opintokerhoja. Opintopiiriryhmän opiskeluprosessia ohjataan ulkoapäin samaan tapaan kuin erilaisia kurssiryhmiä, joten opintopiirin itseohjautuvuus on tavallisesti melko pieni. Ulkoa tapahtuvaa ohjausta suorittavat valtiovalta valtionapusäädöksillä, opiston ylläpitäjä opetussuunnitelmaratkaisuilla ja opettajavalinnoilla sekä opettaja omilla menettelyillään opiskelutilanteessa. Kuitenkin kansalaisopistojen opetustoiminnassa otetaan lähtökohdaksi kansalaisten sivistystarve eli omaehtoinen itsensä kehittäminen.

Kansalaisopistojen opintopiireihin ihmiset tulevat tyydyttämään omaa yksilöllistä sivistystarvettaan. Ihmiset eivät tule niihin kansalaisjärjestöjen jäseninä, vaan yksityisinä kansalaisina. Näin ollen valtakunnallisten tai paikallisten järjestöjen byrokratia ei säätele kansalaisopistojen opintopiirien toimintaa. Voi sanoa, että tässä suhteessa opintopiirit ovat vielä autonomisempia kuin opintokerhot.

\section{Nykyiset valtionapu- järjestelmät ja niiden uudistaminen}

Tällä hetkellä valtionapua välitetään vapaaseen sivistystyöhön usean organisaation kautta. Opintokeskukset saavat valtionapua yleismenoihinsa ja välittävät valtionapua opintokerhoille sekä kurssien ja luentojen järjestäjiile. Kansalais- ja kansanopistot saavat valtionapua perustoimintoihinsa.

Erilliset ns. työmuotoihin perustuvat valtionapujärjestelmät pirstovat vapaan sivistystyön kokonaisuutta. Nykyiset valtionapujärjestelmät ovat lisäksi hyvin organisaatiokeskeisiä. Ratkaisevaa valtionavun määrän ja kohdentamisen kannalta on se, minkä organisaation ja minkä työmuodon piirissä opiskeluryhmä toimii. Lyhytkursseja järjestävät ja toimeenpanevat opintokeskukset, kansanopistot ja kansalaisopistot eli kaikki vapaan sivistystyön organisaatiot. Mutta valtionapumenettely on kussakin organisaatiossa erilainen, vaikka 
opiskeluprosessin järjestämisen kannalta kaikki lyhytkurssit ovat samantyyppisiä eli kokopäiväisiä $1-7$ päivää kestäviä oppimistilaisuuksia.

Opintoryhmätyyppistä opiskelua tapahtuu niin yhdistysten opintokerhoissa kuin kansalaisopistojen opintopiireissäkin. Mutta valtionapumenettely on molempien kohdalla hyvin erilainen, vaikka opiskeluprosessin järjestämisen kannalta opintokerhot ja opintopiirit ovat samantyyppisiä eli $1-3$ tunnin pituisia kerran tai kaksi kertaa viikossa pidettäviä opiskelutilaisuuksia, jotka muodostavat muutaman viikon tai kuukauden kestävän kokoontumisten sarjan. Myös luentojen kohdalla tilanne on samantapainen.

Nykyisillä vapaan sivistystyön valtionapujärjestelmillä on seuraavat heikkoudet. Ensiksi ne asettavat opiskelijat ja opiskelijaryhmät keskenään eriarvoiseen asemaan. "Opintokerhomaisesti" opiskelevat opintoryhmät saavat valtionapua monta kertaa vähemmän kuin muut ryhmät. Toiseksi ne asettavat keinotekoisia raja-aitoja paikalliseen sivistystyöhön ja näin viipaloivat sitä ns. työmuotojen avulla "opintopiireihin",, "opintokerhoihin", ,'lyhytkursseihin" ja "'luentoihin". Kolmanneksi ne estävät opiskelevia ryhmiä toimimasta vapaan sivistystyön oman pedagogiikan mukaisesti.

Nykyiset organișaatiokeskeiset ja työmuotopohjaiset valtionapujärjestelmät rakentuvat perinteisen koulupedagogiikan eli "välityspedagogiikan" aikuissovellutuksille. Tämä on johtanut siihen, että vapaan sivistystyön opiskelutilanteita toteutetaan jopa koulutusteknologisia suunnittelumalleja noudattamalla. Voi jopa väittää, että nykyiset valtionapujärjestelmät estävät vapaan sivistystyön oman pedagogiikan toteuttamisen ja kehittämisen.

Nykyiset valtionapujärjestelmät olisi uudistettava. Uusien järjestelmien lähtökohtana pitäisi olla ennen kaikkea kansalaisten autonomia ja autonomisen toiminnan tukeminen ja lisääminen. Vapaassa sivistystyössä tämä lähtökohta merkitsee ihmisten oma-aloitteisen, omaehtoisen ja omatoimisen opiskelu- ja kulttuuriharrastustoiminnan tukemista ja edistämistä. Vapaan sivistystyön omassa pedagogiikassa tämä lähtökohta merkitsee sitä, että oppijoita ei irroiteta omasta taustastaan, vaan päinvastoin koko opiskeluprosessi tapahtuu oppijoiden omassa elämäntilanteessa eikä sen ulkopuolella. Opiskelutilanteessa jokaisen oppijan yksilölliset kokemukset ja omat näkökulmat todellisuuteen ovat yhtä oikeita ja totuu- dellisia. Yhden ihmisen näkökulma todellisuuteen eli käsitys totuudesta, oikeasta tai väärästä, hyvästä tai pahasta ei ole arvokkaampi kuin toisen ihmisen näkökulma. Kukaan ei siis ole toisten ulko- tai yläpuolella, vaan jokainen toimii sidoksissa tilanteeseen, jossa kenellekään ei voi olla absoluuttista tai objektiivista näkökulmaa. Oppimisprosessin tuloksena jokainen ymmärtää todellisuutta paremmin kuin aikaisemmin.

Ihmisten oma-aloitteisen, omaehtoisen ja omatoimisen opinto- ja kulttuuriharrastustoiminnan tukeminen ja lisääminen edellyttävät sellaista valtionapujärjestelmää, joka ei lähde liikkeelle mistään organisaatiosta tai työmuodosta, vaan joka lähtee liikkeelle opiskelevasta ja harrastavasta ryhmästä ja sen toiminnan tukemisesta. Valtionapujärjestelmän lähtökohtana pitäisi olla opiskelu- ja harrasteryhmän ja siihen kuuluvien kansalaisten autonomian kunnioittaminen, tukeminen ja edistäminen. Tämän mukaan ryhmä päättäisi itse omasta toiminnastaan ja myös niistä lisäresursseista, jotka tulevat ryhmän käyttöön valtionapujärjestelmän välityksellä.

Vapaan sivistystyön nykyiset valtionapujärjestelmät pitäisi korvata uudella ja yhteisellä valtionapujärjestelmällä. Se lähtisi erilaisten paikallisten opiskeluryhmien tasapuolisesta tukemisesta ja auttamisesta. Se olisi luonteeltaan opiskelijaryhmäkeskeinen. Käytännön tasolla tämä merkitsisi sitä, että ryhmä opiskelisi tai harrastaisi nykyisiä työmuototermejä käyttäen samanaikaisesti tai vuorotellen "opintokerhomaisesti", ,'lyhytkurssimaisesti', ,'luentomaisesti"' ja "'opintopiirimäisesti'” yhden ja saman valtionapujärjestelmän sisällä eli edellä sanotusta tiivistäen "opiskeluryhmämäisesti". Toisin sanoen uusi ja yhteinen valtionapujärjestelmä korvaisi kaikki nykyiset organisaatiokeskeiset ja työmuotopohjaiset opintokerhojen, erilaisten lyhytkurssien ja opintopiirien erilliset valtionapujärjestelmät.

Nykyiset valtionapujärjestelmät opintokerhojen valtionapua lukuun ottamatta rajoittavat huomattavasti opiskelu- ja harrastusryhmien autonomiaa. Siksi uuden valtionapujärjestelmän pitäisi lähteä opiskeluryhmien laajasta autonomiasta ja sen lisäämisestä. Mallina tässä voisivat toimia opintokerhot ja niiden autonomia. Kun lisäksi tällaiset autonomiset opintoryhmät ja kulttuuriharrastusryhmät saisivat sen samantasoisen tuen, jonka saavat kansalaisopistojen cpintopiirit, pohja uudelle valtionapujärjestelmälle alkaisi hahmottua. 


\section{Vapaan sivistystyön \\ laitosten ja organisaatioiden uudistaminen}

Kansalaisopistot ovat jo tällä hetkellä paikallisia sivistyskeskuksia, joilla on perinteisesti melko autonominen asema. Lisäksi useimmat opistot ovat kunnallisia. Edellä hahmottelemani kansalaisten sivistystarpeista lähtevä vapaa sivistystyö ja sitä tukeva valtionapujärjestelmä edellyttää paikallisia ja kunnallisia sivistyskeskuksia. Olisi hyvin luonnollista, että nykyisistä kansalaisopistoista kehitettäisiin tällaisia keskuksia, jotka tukisivat ja edistäisivät toimintaalueellaan paikallista vapaata ryhmäopiskelua ja kulttuuriharrastustoimintaa.

Paikallisella tasolla tulisi saman organisaation ja valtionapujärjestelmän piiriin siis sekä nykyinen opintokeskustoiminta että kansalaisopistotoiminta. Kun nyt opintokeskustoiminta saa valtionapua valtakunnallisen ja Helsingissä toimivan opintokeskuksen kautta ja kansalaisopistotoiminta kunnan kautta, uuden järjestelmän mukaan valtion ja kunnan tuki tulisi suoraan paikallisten ja kunnallisten sivistyskeskusten kautta. Luonnollisesti tällainen opiskelu- ja kulttuuriharrastustoiminta tapahtuisi kunkin ryhmän taustayhteisön tai ryhmän jäsenten omaksumassa aatteellisessa hengessä ja ilmapiirissä.

Edellä hahmottamani uusi järjestelmä hävittäisi kansalaisopistotoiminnan ja järjestöllisen sivistystyön välisen kuilun. Tämä kuilu syntyi, kun työväenopistotoiminta erotettiin valtionapumenettelyillä ja käytännön järjestelyillä omaksi neutraaliksi ja tieteenomaiseksi opetustoiminnakseen ja kun kansalaisjärjestöissä tapahtuvaa opiskelua ja kulttuuriharrastustoimintaa alettiin tukea ja organisoida erikseen. Uuden järjestelmän myötä syntyisi kuntatasolla yksi ja yhteinen vapaan sivistystyön järjestelmä.

Uuden järjestelmän mukaisten paikallisten sivistyskeskusten toimintaa johtaisi kunnanvaltuuston valitsema vapaan sivistystyön lautakunta. Varmasti kunnallisten luottamusmiesten johtama sivistyskeskusjärjestelmä kykenisi nykyistä paremmin myös käytännössä edistämään ja tukemaan paikallista sivistystyötä. Tästä ajatuksesta puhui kauniisti järjestöllisen sivistystyön toimikunta, mutta sen edistämistä ei toimikunnan lakiesitys mitenkään erityisesti palvele.

Luonnollisesti tarvitaan myös sellaisia opintotilaisuuksia, joihin tulee osallistujia ja opiskeluryhmiä maakunnan tai koko maan alueelta. Olisi hyvin luonnollista, että nykyisistä kansanopistoista kehitettäisiin maakunnallisvaltakunnallisia sivistyskeskuksia, jotka toimisivat maakunnallisten tai valtakunnallisten opintotilaisuuksien järjestäjinä. Näin tällaisten sivistyskeskusten järjestelmä täydentäisi ja tukisi paikallisten sivistyskeskusten muodostamaa verkostoa. Valtakunnallisella ja maakunnallisella tasolla tulisi siis saman organisaation ja valtionapujärjestelmän piiriin sekä nykyinen kansanopistotoiminta että valtaosa nykyisestä opintokeskusten lyhytkurssitoiminnasta eli alueelliset ja valtakunnalliset lyhytkurssit. Merkittävä askel em. uudistuksen toteuttamiseen mielestäni on se kansanopistotoimikunnan esitys, jonka mukaan kansanopistojen lyhytkurssien vähimmäispituus alennettaisiin 3 päivään ja myös po. kurssien osanottajille maksettaisiin matkakustannukset samaan tapaan kuin nykyisin opintokeskuskurssien osanottajille.

Jos opintokeskuksilta eli tosiasiassa sivistysjärjestöiltä jää valtionavun välitys pois, kuten edellä esittämäni mallin mukaan jäisi, ne voisivat saada takaisin alkuperäisen tarkoituksensa aatteellisten, yhteiskunnallisten ja sivistyksellisten pyrkimysten edistäjänä. Toteuttaakseen tätä tarkoitusta sivistysjärjestöt keskittyisivät tutkimus- ja kokeilutoimintaan, vapaan sivistystyön oman pedagogiikan kehittämiseen, tiedottamiseen ja neuvontatyöhön ja paikallistasolla pää-, sivu- ja osatoimisen henkilöstön tu= kemiseen ja kehittämiseen. Sivistysjärjestöt alkaisivat em. tehtävien myötä muistuttaa enemmän tiede- ja tutkimusyhteisöjä kuin valtion virastoja.

Voidakseen suorittaa näitä tehtäviä sivistysjärjestöjen organisaatio ja rakenne olisi uudistettava. Sivistysjärjestöjen nykyinen keskitetty ja hierarkkinen rakenne olisi purettava ja korvattava hajautetulla ja vähemmän hierarkkisella rakenteella. Sivistysjärjestöjen jäseninä pitäisi siis olla byrokraattisten keskusjärjestöjen sijaan kunta- tai aluepohjaisia paikallisia sivistysjärjestöjä, joiden jäseninä olisivat paikallisten sivistyskeskusten piirissä toimivat opiskelu- ja kulttuuriharrastusryhmät.

Kun sivistysjärjestöillä ei olisi enää nykyistä Helsingin keskustoimistoon keskittyvää valtionavun välitystehtävää, ne voisivat hajauttaa toimintansa tapahtuvaksi pääasiassa maakunnallisella ja paikallisella tasolla. Näin toimien sivistysjärjestöt voisivat, ei vain sanoissa, vaan myös käytännössä tukea ja edistää paikallista sivistystyötä.

Uuden valtionapujärjestelmän, sivistyskeskusverkoston kehittämisen ja sivistysjärjestöjen uudistamisen myötä Suomeen syntyisi 
rakenteeltaan ja ennen kaikkea toiminnaltaan melko hajautettu ja vähän hierarkkinen vapaan sivistystyön järjestelmä. Sen muodostaisivat n. 280 paikallista sivistyskeskusta, n. 80 alueellis-valtakunnallista sivistyskeskusta ja $\mathrm{n}$. 10 valtakunnallispaikallista sivistysjärjestöä. Koko järjestelmän tarkoituksena ja tehtävänä olisi tukea ja edistää nimenomaan kansalaisten ja heidän muodostamiensa autonomisten opiskelu- ja kulttuuriharrastusryhmien toimintaa. Uusi valtionapujärjestelmä rakentuisi vapaan sivistystyön omalle pedagogiikalle ja sille luonteenomaisille ratkaisuille. Vapaan sivistystyön uusi organisaatio, oma pedagogiikka ja sille rakentuva uusi valtionapujärjestelmä tukisivat ja lisäisivät kansalaisten autonomista kansalaistoimintaa huomattavasti paremmin kuin nykyinen käytäntö.

\section{Vapaan sivistystyön kehittämisen organisoiminen}

Edellä olen tuonut eräitä ajatuksia siitä, miten autonomia ilmenee Suomen vapaassa sivistystyössä ja miten erityisesti opiskelu- ja kulttuuriharrastusryhmien autonomiaa voitaisiin tukea ja lisätä kehittämällä vapaan sivistystyön organisoimista ja uudistamalla valtionapujärjestelmiä. Tiedän, että esittämiäni ajatuksia ovat yhtä lailla kehitelleet ja esittäneet monet vapaan sivistystyön '"kentällä' työskentelevät ihmiset. Mikäli olisi aikanaan asetettu yksi ja yhteinen vapaan sivistystyön kehittämistoimikunta, uusia ajatuksia olisi voitu esittää ja kehittää todenteolla. Mutta kuten tiedämme, toisin kävi. Tämän tuloksena meille on tarjolla vain erilaisia suoriteperusteisia valtionapujärjestelmiä eikä mitään vapaan sivistystyön kokonaisuuteen ja sen laadulliseen kehittämiseen tähtääviä esityksiä.

Mielestäni olisi vapaan sivistystyön järjestöjen mitä pikimmin asetettava erillinen kehittämisorganisaatio selvittämään vapaan sivistystyön nykyistä tilaa ja laatimaan esitystä laiksi vapaasta sivistystyöstä ja sen valtionavusta. Tässä asiassa Vapaan sivistystyön yhteisjärjestö ja sen jäsenjärjestöt ovat todella avainasemassa. Lailla vapaasta sivistystyöstä korvattaisiin nykyiset erilliset ja vapaan sivistystyön kokonaisuutta sekä valtakunnallisella että paikallisella tasolla pirstovat lait eli opintokeskuksia, kansalais- ja kansanopistoja koskeva lainsäädäntö. Uuden lain valmistelun ia säätämisen avulla voitaisiin todella sekä kehittää Suomen vapaan sivistystyön järjestelmää että yhdenmukaistaa ja yksinkertaistaa valtionapujärjestelmiä.

Viime kädessä on kysymys siitä, halutaanko vai ei sellaista vapaan sivistystyön järjestelmää, joka lisää ennen kaikkea paikallisten opiskelu- ja kulttuuriharrastusryhmien ja sitä kautta myös kansalaisten autonomiaa. Jos tätä halutaan, vapaan sivistystyön järjestöt asettavat omasta keskuudestaan ja omilla ehdoillaan kehittämisorganisaation valmistelemaan lakia vapaasta sivistystyöstä. Tämän kehittämistyön tuloksena syntyy varmasti sellaisia ehdotuksia, jotka eivät lähde liikkeelle vain valtionhallinnon logiikasta ja valtion menojen supistamisesta, vaan jotka lähtevät liikkeelle vapaan sivistystyön omista ongelmista ja niiden ratkaisemisesta. 